\title{
The Infrastructure Development Compatibility to Enhance Community Welfare
}

\author{
Ali Asfar ${ }^{\mathrm{a} *}$, Soesilo Zauhar ${ }^{\mathrm{b}}$, Siti Rochmah ${ }^{\mathrm{c}}$, Hermawan ${ }^{\mathrm{d}}$ \\ abcd Brawijaya University, Malang, East Java, Indonesia
}

\section{ARTICLE INFORMATION}

\section{Article history:}

Data submission : 07 July 2020

$1^{\text {st }}$ revision: 07 December 2020

Accepted: 05 May 2021

Available online: 31 May 2021

Keywords: development compatibility, infrastructure, community welfare.

\section{ABSTRACT}

This paper aims to describe and analyze the regulations, the interest of actors and the budgets compatibility between the central government, regional governments in infrastructure development of Rokan Hilir District. This research uses a descriptive approach, with qualitative research methods. The research findings show that there is no compatibility between the regulations of the central government and regional governments, therefore the regulations made by the central government cannot be carried out effectively and there are also conflicts with the wishes of local communities. The central government prioritizes the interests of the country as a whole rather than the interests of the people in the region. Infrastructure development in Rokan Hilir Regency is strongly influenced by the Executive Actor and Political Actor (Legislative). The 2012 fiscal year to 2017 indicated that the operating budget is greater than the development budget, this is happened due to the siphoning of the budget to pay the salaries of temporary workers, and other routine expenditures. The implication is that Rokan Hilir Regency unable to carry out some physical development (infrastructure).

2021 FIA UB. All rights reserved.

\section{Introduction}

Infrastructure development can no longer be postponed since it is an integral part of national development and a wheel of economic growth. Therefore, to make sure that Infrastructure Development can improve the welfare of the community and minimize its negative impacts, it is very necessary that the administration process of development and the development program be very precise, as well as gradual and continuous socialization to realize the good, effective and equitable infrastructure development from cities to villages, harmony between the Central Government, the Provincial Government and the Regency/City Government is necessary.

Infrastructure development programs need to pay attention to the harmony between the needs of individuals, institutions, and governments. This harmony is reflected in activities that rely on the interests of the people and government. Activities and goals aim to realize physical and spiritual needs as well as balance in all aspects of life and living. Harmony and even then, reflected between the activities in the past, present and future. The infrastructure development compatibility is very dependent on the level of harmony between each pair of system components.

Semler (1997) stated that the whole system functions with extraordinary or lower effectiveness depend on the level of harmony (congruence), uniformity (consistency), or suitability (fit) between each pair of system components. The harmony of development must be assisted by regional state strategic institutions as partners, the harmony of funding policies, and adheres to the principle of good practice in cooperation in the implementation of development.

Rokan Hilir Regency is one of 12 regencies/cities in Riau Province which is the result of the division of Bengkalis Regency. Rokan Hilir Regency has a wealth of abundant natural resources, both on land, inside the land and at the sea, such as natural resources like Oil. Rokan Hilir Regency, which is rich in natural resources, is also endowed with the potential of the natural

* Corresponding author. e-mail: aliasfar1965@gmail.com 
panorama of the Sea that has not been optimally managed by the Central, Provincial and Regency, as well as private investors. Behind the abundant wealth of natural resources and the enchanting natural panorama of the Aruah Island cluster, the community was not yet prosperous, especially in the coastal sub-district.

The fact that appears in Rokan Hilir District Government needs to become a serious concern of all elements both at the Central Government, the Provincial Government, especially the local Government and the people of Rokan Hilir Regency, for example: 1. The infrastructures such as Roads, Bridges, Seaport, Electricity and Clean Water did not build and maintained. 2. The construction of Regional Office Organizations (OPDs) has not yet been built permanently 3 . Some of the building that have been completed have not occupied and did not properly maintained. 4. The investor's investment has not yet been realized. 5. There are still Many Poor Population, Unemployment, Low Level Education, Health and HDI (Human Development Index) especially for people who live in the Sub-District Region along the coast (Sinaboi Sub-District, Bangko Sub-District, Pekaitan SubDistrict, Kubu Sub-District, Kubu Babussalam SubDistrict, Pasir Limau Kapas Sub-District).

The challenge is how the Regional Government implements infrastructure development policies so that various phenomena can be overcome, of course in this case the need for regulation between the central government, local governments in infrastructure development in Rokan Hilir Regency. Based on the fact, this research is more broadly aimed at describing and analyzing the regulations, the central and regional governments interest, the interests of actors and the budget compatibility between the central government, regional governments in infrastructure development in the Rokan Hilir District.

\section{Theory}

Infrastructure plays an important role as one of the economic growth and development wheel. The existence of adequate infrastructure is very much needed. Physical facilities and infrastructure or often referred as infrastructure are a very important part of the community service system. Various physical facilities are vital to support various government activities, the economy, industry and social activities in the community and government, ranging from energy systems, road transportation, office buildings and schools, to telecommunications, houses of worship and clean water service networks all of which require reliable infrastructure support.

National infrastructure development which is carried out as a joint effort must be evenly distributed in all aspects of life, where every community has the right to participate and enjoy the results fairly in accordance with the human values given by the nation and state towards harmony in life. Infrastructure development in the regions needs to be directed at the realization of improving the welfare of the people (quality of life) in all regions, reducing disparities between regions, and harmonious use of space within the framework of the unitary state of the republic of Indonesia.
Regional development is carried out to achieve the set of goals both in long and short term. The short-term development goal is to support or the successful development of regional projects. The long-term development goal is to develop all villages in Indonesia to become self-sufficient villages through the stages of villages and to pay attention to the harmony of rural and urban development, the balance of obligations between government and society and harmonious integration between sectoral or regional programs with community participation adapted to the needs of the local community in the framework of equitable development throughout Indonesia (Sudiarwo, 1981)

The principle of harmony implies that community development programs pay attention to the compatibility between the needs expressed by individuals, institutions, and government. This compatibility is also reflected in activities that rely on the interests of the people and the government. Activities and goals aim to realize the physical and spiritual need and balance in all aspects of life. The compatibility is reflected between the past and future activities.

Muhammad (2005) states that harmony is the ability to organize something that can be enjoyed by others because it is beautiful. The principle of harmony contains understanding in the interaction between service users and service providers in carrying out work to produce something with high quality and benefit.

The principle of harmony implies in the interaction and integration of actors in the infrastructure sector both with those directly involved in activities in the infrastructure sector and always oriented to ensure the quality of living.

The central government and regional governments both have an interest to achieve an accelerated development. National development aims to create a fair and prosperous society equally both in material and spiritual based on the Pancasila and the 1945 Constitution in the unified Republic of Indonesia, a unified, sovereign, united, and sovereign state of the people in an atmosphere of a safe, peaceful, orderly, and orderly life of the nation dynamic in the world environment of an independent, friendly, orderly, and peaceful (Silalahi, 2009).

\section{Research Method}

Based on the research objectives is to be able to describe, explain the results of research as a whole and depth. The type of research used is qualitative (qualitative research). Data collection techniques in this study include interviews, observation, documentation, and library studies. The informants in this study will be determined on an ongoing basis using a purposive sampling technique. Data analysis techniques in the research is a technique developed by McNabb (2002), namely Grouping the data according to key constructs, identifying bases for interpretation, developing generalizations from the data, Testing Alternative interpretations and forming and/or refining theories from case studies 


\section{Results}

4.1. The compatibility of central government regulation The central government has a high commitment to accelerate infrastructure development throughout the country, especially the implementation of national strategic projects, to meet the basic needs and improve people's welfare. Based on the results of the study, it is found several obstacles in the Rokan Hilir District such as ease of licensing, incomplete spatial planning, land provision, all these need to be communicated and coordinated between ministries/institutions and the community through the regional government so that the development regulation harmony desired by the central government and the community also enjoyed the results of the development.

Infrastructure development is also need regulation as a rule to distinguish which activities are carried out by the central government, and which activities are carried out by local governments, this is important so that conflicts do not occur and overlap. The harmonization of regulations on the distribution of development areas also needs to be regulated, such as physical development areas, agricultural development areas, the construction of industrial areas, settlements and other areas are regulated in the Regional Spatial Plan (RTRW). The research finding shows that there are many regulations that made by the central government cannot be carried out effectively because they are overlap and contradict each other (over regulated) and there are also some regulations that contradict with regional needs.

In addition to overlapping regulations, many regulations sometimes limit government space and cause national development to be hampered. This should not happen, especially in building infrastructure with the frame of Unitary Republic of Indonesia (NKRI). To avoid overlapping regulations that issued by the government and can be applied in the field properly, it requires coordination, communication, and socialization. Then it is necessary to form an official institution that specifically handles regulations and the rule of law supremacy for the welfare of the people to be fair and prosperous.

4.2. The compatibility of local government regulation The commitment of the central government to carry out infrastructure development policies must also be followed by commitment, seriousness, and enthusiasm of the regional government. Those things need to be supported by issuing regulations on the acceleration to smooth the development process and to balance the budgeting regulations in the Provincial Budget. To accelerate infrastructure development in the region, the provincial government must actively engage in formal communication and coordination through existing mechanisms such as Coordination Meetings and others, as well as informal communication and coordination such as the personnel approach to creating a harmony.

Research findings show that the Riau Government province has a high commitment in supporting central government policy, this is marked by the issuance of regulations in the form of Riau Province Regional Regulation No. 2 of 2006 concerning Increasing of Multi-Year Activity Budget Funds, with the objective to increase infrastructure development.
The Government of Rokan Hilir Regency has supported the commitment of the central and provincial governments in making regulations on infrastructure development. Based on the research results it is known that the Rokan Hilir Regency Government has made regulations for increasing tourist visits, such as forming Genpi (Indonesian Enchantment Generation), Pokdarwis (Group Tourism Awareness) and Tourism Villages. However, this regulation has not yet been synchronized with related agencies, such as the Rokan Hilir Public Works and Spatial Planning Office, Housing and Settlement Office (PERKIM) and the Village Community Empowerment Office (PMD), the Transportation Office to build road accessibility, facilities, and other infrastructure.

For good infrastructure development regulation, it is necessary compatible regulation between the central, regional, and inter-regional government organizations, which are supported by appropriate budgets and of course eliminates sectoral egos and each regional apparatus organization. Regional governments need to reciprocally communicate and coordinate with the Central Government intensively and involve academics / experts in making studies / research for a regulation to achieve compatibility so that the regulation is effective, appropriate and can be implemented.

\subsection{The interest compatibility between central, provincial, and regency in infrastructure development.}

The central government has many interests with the region, this happens since the regions have abundant natural resources, moreover, for the integrity of the Unitary Republic of Indonesia (NKRI). The Central Government has made national strategic activities that carried out in the region. The activities and interests of the central region should be in harmony with regional interests and should not be contradictory for the survival of the nation and state.

Research finding shows that the central government prioritizes the interests of the country rather than the interests the region. Empirically, Riau Province is the biggest contributor of crude oil to the country (30\%), especially from Rokan Block, Rokan Hilir Regency, but infrastructure development is not as fast as other cities outside Riau. The development of road infrastructure that connects districts / cities and between provinces is urgently needed for the smooth flow of goods and people. The construction of this access road is the responsibility of the central government, especially inter-regency / city crossroads and the prevention to improve and equitable development and maintain harmony between the interests of the center and the regions.

The lack of harmony also occurred in the needs of the center to preserve the environment through the Ministry of Environment and Forestry. Based on the research findings, there are still many areas in Rokan Hilir Regency that still have forest areas. This happens because the Riau Province Spatial Plan and Rokan Hilir Regency Spatial Plan have not yet been established.

The interests of the Regional Government, both provincial and district / city governments, may not conflict with the interests of the central government and 
must not conflict with the apparatus underneath. The compatibility of regional interests is also reflected in harmony with the interests of subordinates and the community to ensure that development occurs properly, in accordance with Law 23 of 2014 concerning Regional Government.

Ideally, the regional interest's compatibility in the central government is outlined in activities program proposals to the Ministries / Institutions through the National Development Planning Consultation (Musrenbangnas) mechanism, while the regional government compatibility with the apparatus below it is outlined in the proposal through the Musrenbang mechanism of village, District and Province. The research findings show that many of the proposed program mechanisms were not realized, with the classic reason of the limited funds / budget.

\subsection{The interest compatibility of actors}

Research finding shows that infrastructure development in Rokan Hilir Regency is strongly influenced by the Executive and Political Actors (Legislative). This should not have happened if we refer to several opinions about those that influence development, then all actors and related elements should cooperate with each other to achieve the desired development together. This is in line with the opinion of Laode Abdul Wahab (2012) that stated there are 7 development actors who play an important role in accelerating regional progress, they are: 1. Executive, 2. Politicians, 3. Business Actors, 4. Leaders/Religious Organizations, 5. Educational Institutions / Organizers, 6. NGO/CSO, 7. Mass media. The research findings show that the Government of Rokan Hilir Regency has tried to embrace, invite and cooperate with all actors, because the Rokan Hilir Regency Government believes that not all development problems can be resolved by the Executive and Legislative alone. It must be consulted and input from other development actors including parties even the private sector or businessman. By involving other actors, they are expected to feel responsible and feel they have ownership of development as well as their thoughts on how development can be carried out as desired by the community.

\subsection{The development budgets compatibility}

For the community justice, welfare, and prosperity it is very necessary to have a compatibility budget between the Central Government and the Regional Government. The budget does not have to accumulate in the Central Government, but a large budget is needed to the regional government to build infrastructure. Likewise, in preparing the APBD, the infrastructure development budget (direct costs) must be greater than the operational budget (indirect costs).

The research findings show that Rokan Hilir District from 2012 to 2017 operating budget is greater than the development budget, this is happened due to the siphoning of the budget to pay the salaries of temporary workers, and other routine expenditures. The implication is that it can hardly carry out physical development (infrastructure). To maintain the harmony, the Government of Rokan Hilir Regency in 2018 laid off all honorarium of administrative staff which absorbed the Regional Budget of 165 billion per year, selective in the use of funds and reduce routine expenditure, such as
Official Travel costs, unclear training outputs and outcome, capital expenditure (procurement of official cars, computers) and others.

The financial condition of Rokan Hilir Regency is bad which can be seen in the 2018 Regional Budget, which is direct costs about Rp. $792,315,176,172$ while Indirect costs Rp. 933,719,327,891. Direct (development) expenditure should be greater than indirect (routine) expenditure. The wisdom of the regional leaders, especially the Rokan Hilir Regent and his apparatus, was asked, especially the TAPD Team, which was chaired by the Regional Secretary to maintain the harmony of the APBD usage, of course on a priority scale, the physical activity was postponed until the finances improved with the intention that the government should continue as it should.

\section{Discussion and conclusion}

Based on the description that stated before, it is necessary to harmonize the budget in infrastructure development, since if the budget is not compatible then the development will not be as good as desired. Especially in a bad financial condition, it is very necessary to harmonize the budget, to be able to sort out, choose which ones are the priorities and choose which one that can be postponed. Even tough, the Rokan Hilir District Government through the Rokan Hilir Regency has embraced and synergies all development actors among regional apparatus organizations, development will still not go according to the community's expectations if it is not supported by funds/development budgets in the APBD due to expectation the private sector (investors) in the current infrastructure conditions will be difficult to implement.

The government regulations compatibility has not been running well and effectively between the central government, regional governments, district governments and government apparatus below. It is still not easy to administer licenses create a difficulty for investors to invest their capital. Based on the research results, there are investors who want to invest their capital to open a business but because of the problem of licensing, the investor did not invest in Rokan Hilir Regency. The next problem is the legal status of the land to be built both by the government and for investors. The National Land Agency will not dare to issue a certificate of land ownership, if the land status is unclear, especially if the land is included in a forest area that has not been converted according to the rules and regulations.

The interest compatibility of the central government has not been felt by the lower levels of society, there are still complaints by people for the central government to pay their attention to the needs/ desires in accordance with the needs of the community. Then the central government prioritizes the interests of the country rather than the interests of the people of the region, even though the results of the wealth of the region's natural resources have been exploited since before the independence of Indonesia, likewise forests and marine products were exploited infinitely.

To achieve well infrastructure development and to improve the welfare of the community, especially in the coastal areas of Rokan Hilir Regency, the Government of Rokan Hilir Regency through the Rokan Hilir Regent 
has approached, communicated, and coordinated with actors who influence development, to create harmony.

In the condition of limited funds for infrastructure development, the Rokan Hilir District Government through the Regent has ordered its Regional Apparatus Organization (OPD) to find other sources of funds. They seize funds at the Ministries / Institutions in the Center to be brought to Rokan Hilir Regency, such as the Special Allocation Fund (DAK) both physical and nonphysical DAK.

The inconsistency development budget with the routine (operational) budget, makes development slow or not smoothly achieved in the development of Rokan Hilir Regency especially infrastructure development, this is also exacerbated by the absence of investors entering to invest their capital in building and trying in Rokan Hilir Regency

\section{References}

McNabb, E. (2002). Research Method in Public Administration and Nonprofit Management, Quantitative and Qualitative Approaches. New York.

Muhammad, K. (2005). Ilmu Sosial Budaya Dasar. PT. Citra Aditya Bakti.

Siagian, P. (2016). Administrasi Pembangunan Konsep, Dimensi, dan Strategi. PT. Bumi Aksara Jakarta.

Silalahi, B. (2009). Otonomi Derah Percontohan. Restu Agung.

Soemardi, W., bduh, M., Wirahadikusumah, D. \& Pujoartanto, N. (2009). Konsep Earned Value untuk Pengelolaan Proyek Konstruksi. Institut Teknologi Bandung Press.

Semler, S. (1997). Systematic Agreement: A Theory of Organizational Alignment. Human Resource Development, 8(1) 4-10.

Sudiarwo, D. (1981). Pokok-Pokok Pemerintahan Di Daerah Dan Pemerintahan Desa. Angkasa Bandung. 